\title{
Influence of binder type and process parameters on the compression properties and microbial survival in diclofenac tablet formulations
}

\author{
John Oluwasogo Ayorinde*, Oludele Adelanwa Itiola, Oluwatoyin Adepeju Odeku, \\ Michael Ayodele Odeniyi
}

Department of Pharmaceutics and Industrial Pharmacy, University of Ibadan, Nigeria

\begin{abstract}
The influence of binder type and process parameters on the compression properties and microbial survival in diclofenac tablet formulations were studied using a novel gum from Albizia zygia. Tablets were produced from diclofenac formulations containing corn starch, lactose and dicalcium phosphate. Formulations were analyzed using the Heckel and Kawakita plots. Determination of microbial viability in the formulations was done on the compressed tablets of both contaminated and uncontaminated tablets prepared from formulations. Direct compression imparted a higher plasticity on the materials than the wet granulation method. Tablets produced by wet granulation presented with a higher crushing strength than those produced by the direct compression method. Significantly higher microbial survival $(\mathrm{p}<0.05)$ was obtained in formulations prepared by direct compression. The percent survival of Bacillus subtilis spores decreased with increase in binder concentration. The study showed that Albizia gum is capable of imparting higher plasticity on materials and exhibited a higher reduction of microbial contaminant in the formulations. The direct compression method produced tablets of reduced viability of microbial contaminant.
\end{abstract}

Uniterms: Tablets/production. Tablets/microbial analysis. Direct compression/tablets production. Wet granulation/tablets production. Tablets/microbial contamination. Microbial survival/in tablets. Albizia gum/use/tablets production.

A influência do tipo de ligante e os parâmetros do processo de propriedades de compressão e sobrevivência microbiana em comprimidos de diclofenaco foram estudados utilizando uma nova goma de Albizia zygia. Os comprimidos foram produzidos a partir de formulações de diclofenaco contendo amido de milho, lactose e fosfato bicálcico. As formulações foram analisadas usando os gráficos de Heckel e Kawakita. A determinação da viabilidade microbiana nas formulações foi feita nos comprimidos contaminados e não contaminados preparados a partir de formulações. A compressão direta confere maior plasticidade dos materiais do que o método de granulação úmida. Comprimidos produzidos por granulação úmida apresentaram maior força de esmagamento do que aqueles produzidos pelo método de compressão direta. Observou-se sobrevivência significativamente maior $(\mathrm{p}<0,05)$ em formulações preparadas por compressão direta. A sobrevivência percentual dos esporos de Bacillus subtilis diminuiu com o aumento da concentração do agregante. O estudo mostrou que a goma de Albizia é capaz de conferir maior plasticidade aos materiais e apresentou maior redução da contaminação microbiana nas formulações. O método de compressão direta produziu comprimidos com viabilidade reduzida de contaminantes microbianos.

Unitermos: Comprimidos/produção. Comprimidos/análise microbiológica. Comprimidos/contaminação microbiana. Compressão direta/produção de comprimidos. Granulação úmida/produção de comprimidos. Sobrevivência microbiana/em comprimidos. Goma de Albizia/uso.

*Correspondence: J. O. Ayorinde. Department of Pharmaceutics and Industrial Pharmacy, Faculty of Pharmacy, University of Ibadan, Ibadan 20005, Nigeria. E-mail: shogo205@yahoo.com 


\section{INTRODUCTION}

Direct compression is highly efficient, less laborious, and increasingly becoming more popular than both compression granulation and wet granulation methods in the manufacturing of tablets. However, few drug powders can be tabletted by the direct compression method, while most drugs need the incorporation of other substances referred to as tablet excipients in order to achieve satisfactory properties such as strength, disintegration and dissolution times. One such excipient is the binding agent. Examples of binders include gelatin, polyvinylpyrrolidone (PVP), the cellulose derivatives (such as carboxyl methylcellulose) and pregelatinized starches. Binding agents employed in formulations are known to undergo a high degree of plastic deformation during compression and are forced into interparticulate spaces, where they increase the area of contact between the particles and form strong solid bonds (Itiola, Pilpel, 1991). The process of formation of these solid bonds is capable of exerting a lethal effect on microbial contaminants during tabletting (Ayorinde, Itiola, 2010).

Manufacturing processes have been known to produce a drop of about $70 \%$ in the viable count compared to the original raw materials of pharmaceutical products. The granulation step prior to tabletting often employs elevated temperatures $\left(10-80^{\circ} \mathrm{C}\right)$ for prolonged periods of time, and is known to destroy the vegetative forms of microorganism (Fry, Greaves, 1995). The shear stress manifested during compression depends largely on the principal mode of consolidation of the formulation, which can be either by fragmentation or plastic flow, with plastic flow having been shown to be a highly effective mechanism for microbial kill even at low compression pressures (Blair et al., 1991).

More than 15 different mathematical descriptions of the compaction process have been computed in the literature, and several of these, including those of Heckel and Kawakita and Ludde, have been validated for pharmaceutical systems. In the present work, Heckel and Kawakita plots have been used to study the compressional behaviour of diclofenac with three different excipients. Also, the effects of different processing methods and binders on both the compressional properties and microbial survival in tablets have been studied.

Albizia gum is a gummy exudate from the trunk of the Albizia zygia tree (family Leguminosae). The tree is a well known tree in Africa and has wide distribution from Senegal in West Africa to east Africa, with no variation in term of quality of gum produced (World Agroforestry, 2011). Albizia gum has superior binding properties than gelatin in tablet formulations (Odeku, 2005). Hence, this study seeks to investigate the effect of Albizia gum on survival of microbial contaminant and compare the mechanical properties of diclofenac tablets containing Albizia gum with those containing gelatin as binding agents.

Diclofenac, an important non-steroidal anti inflammatory drug (NSAID), was chosen in the present study due its poor compressibility. The formulation requires a binder, among other excipients, to form tablets of satisfactory mechanical strength. Bacillus subtilis, a spore-forming bacterium, was chosen as the microbial contaminant due to its resistance to destruction by both physical and chemical agents.

\section{MATERIALS AND METHODS}

The materials used in this work were diclofenac (Unique Chemicals, Gujarat, India), corn starch, dicalcium phosphate (DCP) and lactose (Sam Pharmaceuticals, Ilorin, Nigeria), Gelatin BP (Hopkins and Williams, Chadwell Health, Essex, UK), Bacillus subtilis spores (Laboratory stock culture, Department of Veterinary Microbiology and Parasitology, University of Ibadan), Nutrient agar $\mathrm{pH}$ 6.0, Nutrient broth $\mathrm{pH}$ 6.8, Sabouraud dextrose agar pH 5.6, MacConkey broth (Department of Pharmaceutical Microbiology, University of Ibadan.), and Albizia gum (from Albizia zygia tree, Botanical gardens, University of Ibadan).

\section{Collection and Purification of Albizia zygia gum}

The trunk of Albizia zygia tree was incised and the exudate was allowed to harden, after which it was collected from the tree. The hardened exudate was dried in a hot air oven at $40^{\circ} \mathrm{C}$ until brittle, and then crushed to powder, using a mortar and pestle. The powder was further size-reduced by passing through an Osterizer blender (Model 857, Willamette Industries, Bowling Green, Kentucky, USA). The powdered gum was hydrated in double-strength chloroform water for 5 days with intermittent stirring. The resultant mucilage was strained through a clean calico cloth to remove extraneous materials. The gum was then precipitated from solution with $95 \% \mathrm{v} / \mathrm{v}$ ethanol. The precipitated gum was filtered, washed with diethyl ether and then dried in hot air oven at $40^{\circ} \mathrm{C}$ (Odeniyi and Jaiyeoba, 2009).

\section{Preparation of inoculum}

An overnight culture (18 h) was prepared from $\mathrm{Ba}$ cillus subtilis spores (Laboratory stock culture obtained from Department of Veterinary Microbiology and Parasitology, University of Ibadan). One (1) $\mathrm{mL}$ of the overnight 
culture was placed in $9 \mathrm{~mL}$ of sterile distilled water and 2 $\mathrm{mL}$ of the culture was placed in sterile glass mortars and allowed to dry at $37^{\circ} \mathrm{C}$ for $48 \mathrm{~h}$.

\section{Preparation of powder formulations}

The binary mixtures of diclofenac and the excipients were prepared by mixing diclofenac and each of the excipient powders in the ratio of 1:1 (Sujja-areevath et al., 1996). The formulations formed were: diclofenac formulation containing corn starch (DCS), diclofenac formulation containing lactose (DL) and diclofenac formulation containing dicalcium phosphate (DDCP). Each batch was mixed for $5 \mathrm{~min}$ in a Kenwood planetary mixer. The powder mixtures were then stored in airtight containers and labelled appropriately. The formulation components and process parameters are given in Table I.

\section{Contamination of materials}

Quantities (10 g) of the prepared diclofenac formulations were gently mixed in the Bacillus subtilis-contaminated glass mortars by the method of increasing quantities (Plumpton et al., 1986) to give an even dispersion of the contaminating organism within the individual samples. Viable counts of microbial contaminants were carried out on the contaminated and uncontaminated materials.

\section{Preparation of granules}

Batches (250 g each) of diclofenac formulations containing diclofenac $(50 \% \mathrm{w} / \mathrm{w})+$ corn $\operatorname{starch}(50 \% \mathrm{w} / \mathrm{w})$ (DCS), diclofenac $(50 \% \mathrm{w} / \mathrm{w})+$ lactose $(50 \% \mathrm{w} / \mathrm{w})(\mathrm{DL})$, and diclofenac $(50 \% \mathrm{w} / \mathrm{w})+\mathrm{DCP}(50 \% \mathrm{w} / \mathrm{w})(\mathrm{DDCP})$ were used.

Each formulation batch was dry-mixed for $5 \mathrm{~min}$ in a Kenwood planetary mixer and then moistened with either $30 \mathrm{~mL}$ of distilled water or appropriate quantities of mucilages and solutions of Albizia zygia gum and gelatin respectively, to give $1 \%$ or $4 \% \mathrm{w} / \mathrm{w}$ of the gum and gelatin in the final granule formulation. Massing was continued for $5 \mathrm{~min}$ and the wet masses were granulated by passing them manually through a number 12 mesh sieve $(1400 \mu \mathrm{m})$. The granules produced were dried in a hot air oven for $18 \mathrm{~h}$ at $50{ }^{\circ} \mathrm{C}$ and thereafter re-sieved through a number 16 mesh sieve $(100 \mu \mathrm{m})$. The granules were stored in airtight containers.

\section{Preparation of tablets}

Quantities (500 mg) of the powder and granule formulations of contaminated and uncontaminated diclofenac formulations were compressed for $1 \mathrm{~min}$ into tablets with pre-determined loads, using a Carver hydraulic hand press (Model C, Carver Inc, Menomonee Falls, Wisconsin, USA), using a $12.5 \mathrm{~mm}$ die and flat-faced punches. Before each compression, the die and punches were lubricated with a $2 \% \mathrm{w} / \mathrm{v}$ dispersion of magnesium stearate in ether. After compression, tablets were stored in airtight containers for $24 \mathrm{~h}$ to allow for elastic recovery and hardening and to prevent falsely low yield values. The weights and dimensions of the tablets were determined to within $\pm 1 \mathrm{mg}$

TABLE I - Formulation components and process parameters for diclofenac tablets

\begin{tabular}{|c|c|c|c|}
\hline Formulation & Components & Binder & Compression Process \\
\hline DCSdc & $50 \%$ Diclofenac $+50 \%$ Corn starch & None & Direct compression \\
\hline DLdc & $50 \%$ Diclofenac $+50 \%$ Lactose & None & Direct compression \\
\hline DDCPdc & $50 \%$ Diclofenac $+50 \%$ Dicalcium phosphate & None & Direct compression \\
\hline DCSg & $50 \%$ Diclofenac $+50 \%$ Corn starch & $\begin{array}{l}\text { Gelatin } \\
1 \% \mathrm{w} / \mathrm{w} \text { and } 4 \% \mathrm{w} / \mathrm{w}\end{array}$ & Wet granulation \\
\hline DLg & $50 \%$ Diclofenac $+50 \%$ Lactose & $\begin{array}{c}\text { Gelatin } \\
1 \% \mathrm{w} / \mathrm{w} \text { and } 4 \% \mathrm{w} / \mathrm{w}\end{array}$ & Wet granulation \\
\hline DDCPgg & $50 \%$ Diclofenac $+50 \%$ Dicalcium phosphate & $\begin{array}{l}\text { Gelatin } \\
1 \% \mathrm{w} / \mathrm{w} \text { and } 4 \% \mathrm{w} / \mathrm{w}\end{array}$ & Wet granulation \\
\hline $\mathrm{DCSg}$ & $50 \%$ Diclofenac $+50 \%$ Corn starch & $\begin{array}{l}\text { Albizia gum } \\
1 \% \mathrm{w} / \mathrm{w} \text { and } 4 \% \mathrm{w} / \mathrm{w}\end{array}$ & Wet granulation \\
\hline DLg & $50 \%$ Diclofenac $+50 \%$ Lactose & $\begin{array}{c}\text { Albizia gum } \\
1 \% \mathrm{w} / \mathrm{w} \text { and } 4 \% \mathrm{w} / \mathrm{w}\end{array}$ & Wet granulation \\
\hline DDCPg & $50 \%$ Diclofenac $+50 \%$ Dicalcium phosphate & $\begin{array}{l}\text { Albizia gum } \\
1 \% \mathrm{w} / \mathrm{w} \text { and } 4 \% \mathrm{w} / \mathrm{w}\end{array}$ & Wet granulation \\
\hline
\end{tabular}


and $0.01 \mathrm{~mm}$ respectively. The relative densities (D) of the tablets were calculated using the following equation:

$$
\mathrm{D}=\mathrm{W} / \mathrm{V}_{\mathrm{t}} \cdot \rho_{\mathrm{s}}
$$

where $\mathrm{W}=$ weight of tablet; $\mathrm{D}=$ relative density of the tablet; $V_{t}=$ volume of the tablet, and $\rho_{\mathrm{s}}=$ Particle density of the material

\section{Analysis of compressional properties}

The compressional properties of diclofenac with the three different excipients were studied using Heckel and Kawakita equations.

\section{Determination of viability}

Viable counts were carried out on the compressed tablets of both contaminated and uncontaminated tablets prepared from powder and granule formulations. These were compared with the viable counts of uncompressed contaminated materials.

Approximately 1-g quantities of contaminated (or uncontaminated) tablets were disintegrated in $9 \mathrm{~mL}$ of sterile distilled water. The resultant suspension was serially diluted and $1 \mathrm{~mL}$ volume of the 1-in-100 dilution was transferred immediately into $10 \mathrm{~mL}$ melted and cooled nutrient agar. Using pour-plate method, the content of the nutrient agar bottle was transferred into the sterile Petri dish. The agar was allowed to set and then incubated at $37{ }^{\circ} \mathrm{C}$ for $24 \mathrm{~h}$. Survival, estimated as the mean of quadruplicate determinations, was expressed for the contaminated tablets as a percentage relative to uncompressed control contaminated materials.

\section{Tensile strength tests}

The tensile strength of tablets was determined at room temperature by diametrical compression (Fell, Newton, 1970) using a tablet hardness tester, 400060, Model:EHHO1 (DBK Instrument, Mumbai, India). All measurements were made in quadruplicate.

\section{RESULTS AND DISCUSSION}

\section{Compressional properties}

Representative Heckel and Kawakita plots for diclofenac formulations are shown in Fig. 1 and Fig. 2 respectively. High linearity with correlation coefficients of generally greater than 0.95 was obtained at the second phase of the plots, which generally commenced at the applied pressure of $113.230 \mathrm{MNm}^{-2}$ for diclofenac formulations. Such high linearity is often experienced with comparatively soft materials that undergo plastic deformation while retaining different degrees of porosity depending on the initial packing arrangement in the die.

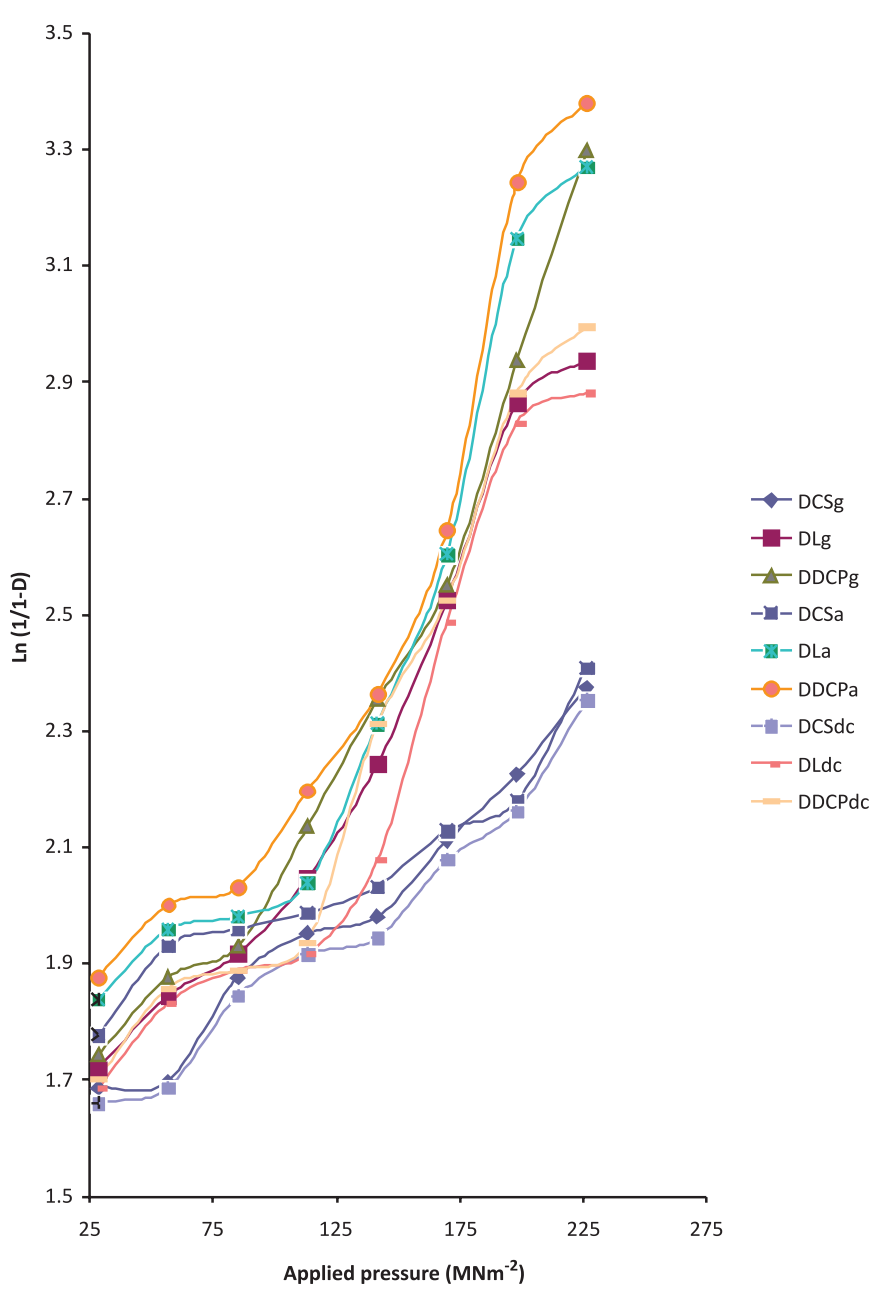

FIGURE 1 - Heckel plots for Diclofenac tablet formulations.

The mean yield pressure $\left(\mathrm{P}_{\mathrm{y}}\right)$, and the measure of the total amount of plastic deformation $\left(\mathrm{P}_{\mathrm{k}}\right)$ occurring during compression, both of which are inverse plasticity parameters were derived from the Heckel and Kawakita plots respectively and were used in comparing the compressional properties of the formulations. The values for these parameters are presented in Table II.

The mode of consolidation of diclofenac formulations was found to be dependent on the nature of the excipient present in the formulation. Formulations containing corn starch (DCS) deformed mainly by plastic flow, while formulations containing a fracturing excipient, DCP (DDCP), consolidated by fragmentation. Formula- 


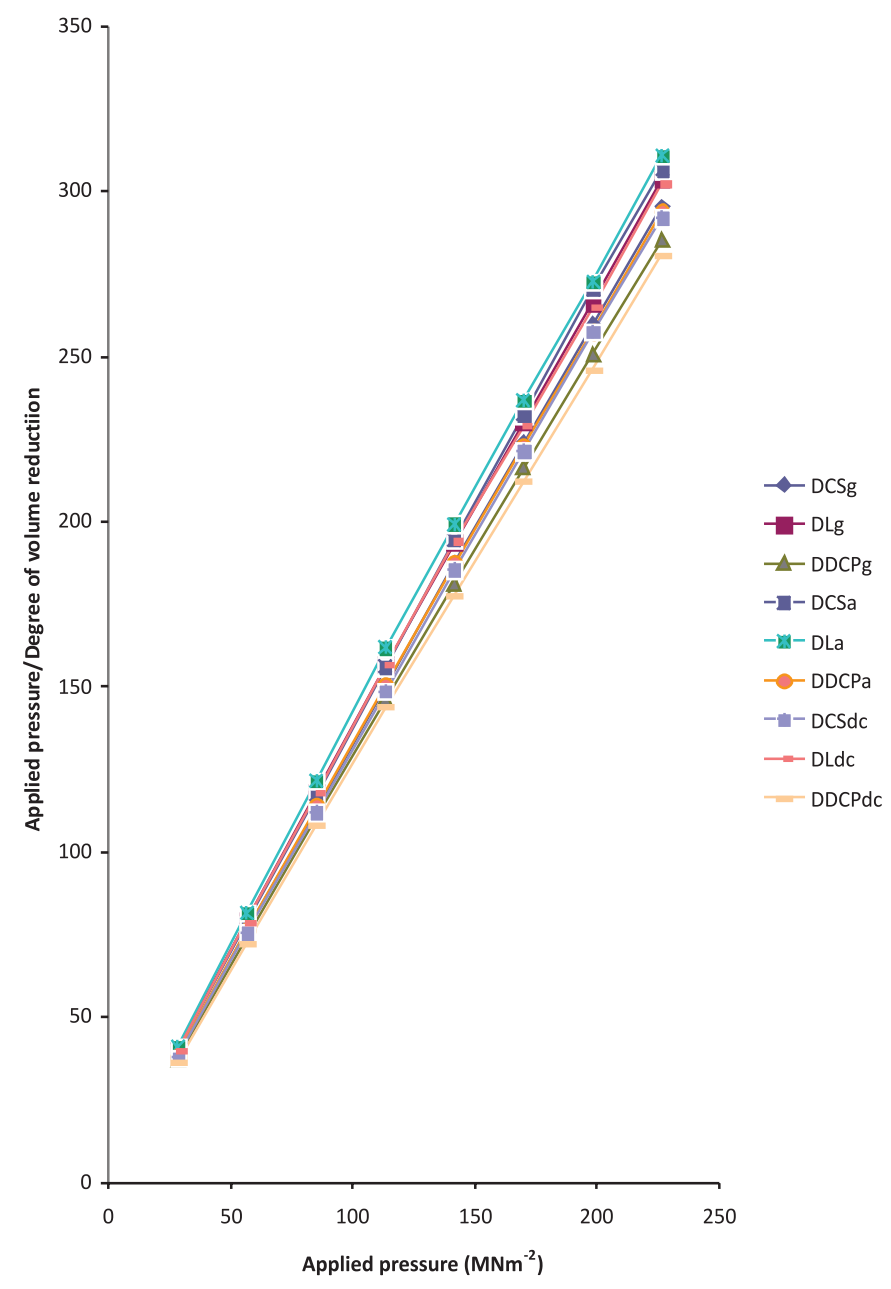

FIGURE 2 - Kawakita plots for Diclofenac formulations. tions containing lactose (DL) showed an initial curve at the early stage of compression, the curve became linear at the later stage. This showed that DL deformed by fragmentation at the early stage of compression, followed by plastic deformation at the later stage. These results show that the mode of consolidation of the drug, diclofenac, is largely dependent on the nature of the excipient used in the formulation.

\section{Mean yield pressure $\left(P_{y}\right)$ and $P_{k}$}

The yield pressure is defined as the stress at which plastic deformation of the particles commences and can be derived from the linear part of the Heckel plot while $P_{k}$ is another pressure term which represents the pressure required to reduce the powder bed by $50 \%$ and is obtainable from Kawakita plots (Adams et al., 1994). Both Py and Pk have an inverse relationship with plasticity of materials.

DCS was found to have the least $\mathrm{P}_{\mathrm{y}}$ and $\mathrm{P}_{\mathrm{k}}$ values. The ranking of $\mathrm{P}_{\mathrm{y}}$ and $\mathrm{P}_{\mathrm{k}}$ values among diclofenac formulations was DDCP $>$ DL $>$ DCS. The difference was significant according to ANOVA $(p<0.05)$. This implies that the onset of plastic deformation occurred at lowest pressure in DCS. This suggests that corn starch as an excipient will induce faster onset and extent of plastic flow in diclofenac formulations than either lactose or DCP and that corn starch is able to increase the softness of the formulation and its ability to deform plastically under pressure more than lactose and DCP.

The deformation mechanism of a specific particle

TABLE II - Values of relative density of tablets at compression pressure of $113.23 \mathrm{MNm}^{-2}(\mathrm{D}), \mathrm{P}_{\mathrm{y}}$ and $\mathrm{P}_{\mathrm{k}}$ for diclofenac formulations

\begin{tabular}{lllccc}
\hline Formulation & Compression Method & Binder/Concentration & $\mathrm{D}$ & $\mathbf{P}_{\mathbf{y}}$ & $\mathbf{P}_{\mathbf{k}}$ \\
\hline DCS & Direct compression & None & 0.853 & 32.258 & 0.205 \\
DCS & Wet granulation & None & 0.855 & 105.263 & 0.217 \\
& & Gelatin, 1\% & 0.858 & 103.093 & 0.208 \\
& & Gelatin, 4\% & 0.867 & 83.333 & 0.165 \\
& & Albizia gum, 1\% & 0.863 & 78.125 & 0.187 \\
& & Albizia gum, 4\% & 0.874 & 64.103 & 0.082 \\
\hline DL & Direct compression & None & 0.853 & 90.090 & 0.319 \\
DL & Wet granulation & None & 0.868 & 112.359 & 0.328 \\
& & Gelatin, 1\% & 0.871 & 108.696 & 0.276 \\
& & Gelatin, 4\% & 0.879 & 95.238 & 0.215 \\
& & Albizia gum, 1\% & 0.876 & 82.644 & 0.214 \\
\hline DDCP & Direct compression & Albizia gum, 4\% & 0.885 & 71.429 & 0.113 \\
DDCP & Wet granulation & None & 0.856 & 92.592 & 0.370 \\
& & Gelatin, 1\% & 0.878 & 312.500 & 0.441 \\
& & Gelatin, 4\% & 0.882 & 294.118 & 0.399 \\
& & Albizia gum, 1\% & 0.890 & 158.730 & 0.278 \\
& & Albizia gum, 4\% & 0.889 & 217.391 & 0.264 \\
\hline
\end{tabular}


is affected mainly by the molecular and crystal structure of the material (Rasenack, Muller, 2002). Hard, brittle materials which have greater shear strength than tensile strength tend to fragment more easily than soft materials, which have lower shear strength than tensile strength. Particles also have a critical diameter at which the densification mechanism turns from fragmentation to plastic deformation when particle size decreases (Roberts, Rowe, 1996). This appears to be the case with DL in this study, in which the formulation fragmented at the early stage of the compression and exhibited plastic deformation at the later stage.

The $\mathrm{P}_{\mathrm{y}}$ and $\mathrm{P}_{\mathrm{k}}$ values for powder formulations produced by the direct compression method of tablet production were lower than the values for the granule formulations produced by the wet granulation method (with no binder). This is probably due to fragmentation of the granules at low pressures and subsequent filling of void spaces between the particles (Itiola, Pilpel, 1991). This therefore suggests that direct compression is capable of imparting more plasticity to materials than the wet granulation method in tablet production. However, as binders were incorporated into the formulations in the wet granulation method, the $\mathrm{P}_{\mathrm{y}}$ values decreased and further decreased as binder concentration increased. This is in agreement with previous work (Alebiowu, Itiola, 2001), which reported that onset of plastic deformation in formulation occurred at lower pressures with increase in binder content. The $\mathrm{P}_{\mathrm{y}}$ and $\mathrm{P}_{\mathrm{k}}$ values obtained for formulations containing Albizia gum were generally lower than those of formulations containing gelatin as binder $(\mathrm{P}<0.05)$. This suggests that
Albizia gum as a binder has superior qualities over gelatin in improving the softness and plasticity of materials.

The differences between $\mathrm{P}_{\mathrm{y}}$ and $\mathrm{P}_{\mathrm{k}}$ (Table II) values are probably due to the fact that, while Py relates essentially to the onset of plastic deformation, $\mathrm{P}_{\mathrm{k}}$ relates to the amount of plastic deformation occurring during the compression process, especially with plastic deformation being a time dependent phenomenon (Oloniyon et al.,1998).

\section{Tensile strength $(T)$ of tablets}

Bond strength is measurable by the tensile strength (T) of tablets (Itiola, Pilpel,1991; Fry, Greaves, 1995). Tensile strength has been used in this present study to assess the mechanical properties of diclofenac tablets, in which the binding properties of gelatin and Albizia gum were compared.

The results of the tensile strength on diclofenac tablet formulations are presented in Table III, while the representative plots of $\log$ tensile strength versus relative density of tablets are shown in Figure 3. Correlation coefficients of generally greater than 0.970 were obtained in all the formulations. This could be attributed to different types of forces that are acting between the constituent particles which include the interparticulate forces of attraction or van der Waals' forces, mechanical interlocking and other forces that operate between particles as they are brought into closer contact between the particles. The greater the effective surface area of contact, the greater is the degree of bonding, and, in effect, the greater the tensile strength.

TABLE III - Granule properties of the formulations

\begin{tabular}{llcccc}
\hline Formulations & Binder/concentration & $\begin{array}{c}\text { Mean granule size } \\
(\mu \mathrm{m})\end{array}$ & $\begin{array}{c}\text { Loose bulk density } \\
\left(\mathrm{g} \mathrm{cm}^{3}\right)\end{array}$ & $\begin{array}{c}\text { Particle density } \\
\left(\mathrm{g} \mathrm{cm}^{3}\right)\end{array}$ & $\begin{array}{c}\text { Relative density at } \\
\text { zero pressure }\end{array}$ \\
\hline DCS & None & 605 & 0.297 & 1.456 & 0.204 \\
& Gelatin, 1\% & 650 & 0.308 & 1.455 & 0.212 \\
& Gelatin, 4\% & 710 & 0.340 & 1.454 & 0.234 \\
& Albizia gum, 1\% & 800 & 0.345 & 1.454 & 0.237 \\
& Albizia gum,4\% & 850 & 0.372 & 1.453 & 0.256 \\
\hline DL & None & 500 & 0.353 & 1.489 & 0.237 \\
& Gelatin, 1\% & 565 & 0.359 & 1.489 & 0.241 \\
& Gelatin, 4\% & 630 & 0.363 & 1.487 & 0.244 \\
& Albizia gum, 1\% & 680 & 0.389 & 1.486 & 0.262 \\
& Albizia gum, 4\% & 730 & 0.456 & 1.484 & 0.307 \\
\hline DDCP & None & 440 & 0.398 & 2.166 & 0.184 \\
& Gelatin, 1\% & 480 & 0.430 & 2.165 & 0.199 \\
& Gelatin, 4\% & 560 & 0.433 & 2.164 & 0.200 \\
& Albizia gum, 1\% & 610 & 0.480 & 2.163 & 0.222 \\
& Albizia gum, 4\% & 650 & 0.505 & 2.160 & 0.234 \\
\hline
\end{tabular}




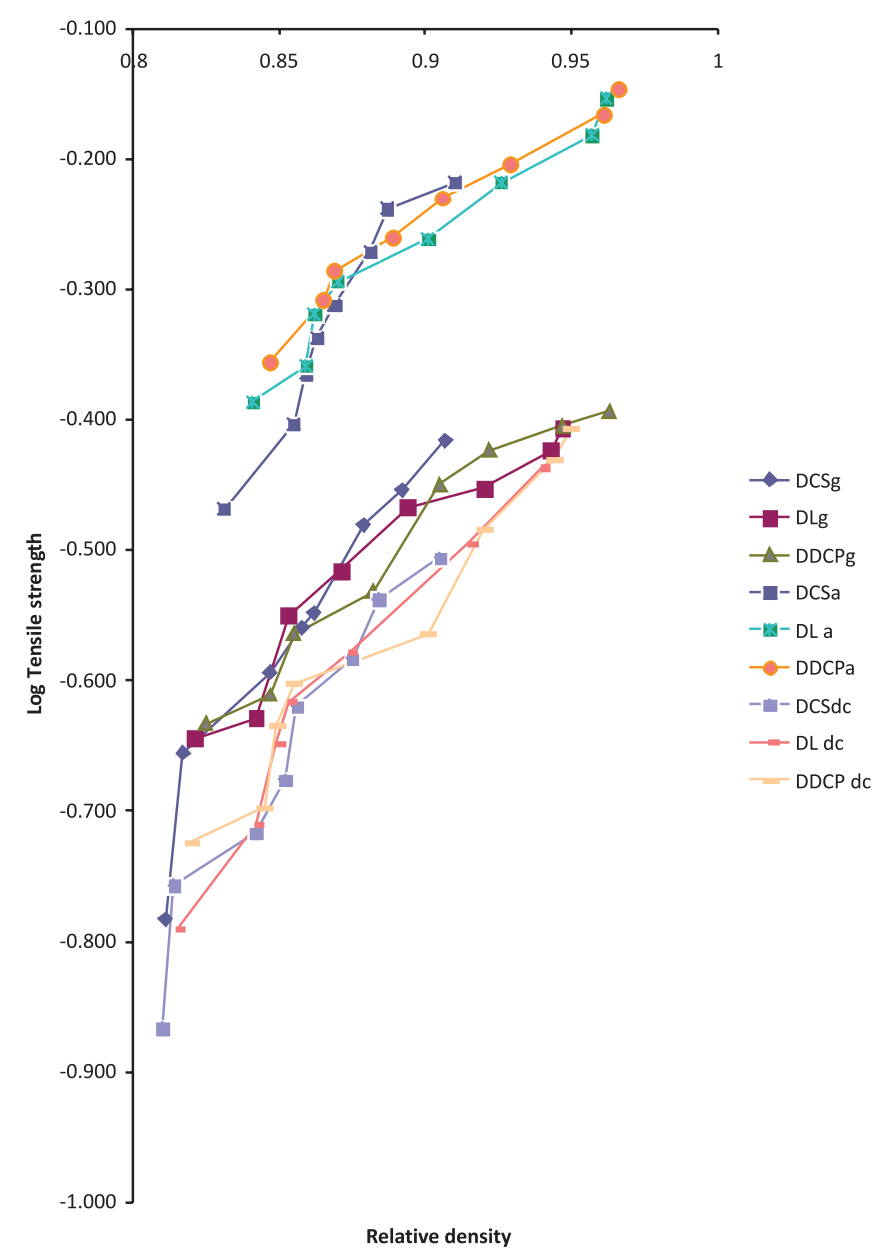

FIGURE 3 - Representative plots of log tensile strength versus relative density for diclofenac formulations.
DDCP generally exhibited the highest values of T among diclofenac formulations. The ranking was DDCP $>$ DL $>$ DCS. This result shows that formulations containing fracturing materials produced tablets of higher tensile strength. Correlations have been found between fracture strength and compression behaviour of particles (Fichtner, 2007). The deformability of pellets made of microcrystalline cellulose could be related to their tensile and shear strength, and was found to be reduced for stronger pellets (Bashaiwoldu et al., 2004).

A higher crushing strength was obtained for granules (in tablets produced by wet granulation with no binder) than for powders of the same formulation (in tablets produced by direct compression method). This could be explained by the variation in the intra-granular or intraparticle porosity. The higher bulk density of the powders is an indication of reduced intra-particle porosity, which might have led to tablets of higher crushing strength.

Upon incorporation of binders, the values of $\mathrm{T}$ were found to be higher in tablets containing Albizia gum than those containing gelatin as binder. This could be as a result of a higher amount of plastic deformation which occurred during the compression process in the formulation containing Albizia gum than those in which the binder used was gelatin. This is evidenced by low $\mathrm{P}_{\mathrm{y}}$ and $\mathrm{P}_{\mathrm{k}}$ values obtained in the formulations containing Albizia gum.

Tablets containing Albizia gum exhibited higher values of $\mathrm{T}(\mathrm{p}<0.05)$ than those containing gelatin. It can therefore be inferred that Albizia gum could be more useful as a binder than gelatin in tablet production.

TABLE III - Values of Tensile strength (T) of diclofenac tablets at relative density of 0.900

\begin{tabular}{|c|c|c|c|}
\hline Formulation & Compression method & Binder/Concentration & Tensile strength, $\mathrm{T}\left(\mathrm{MN} / \mathrm{m}^{2}\right)$ \\
\hline$\overline{\mathrm{DCS}}$ & $\begin{array}{l}\text { Direct compression } \\
\text { Wet granulation }\end{array}$ & $\begin{array}{l}\text { None } \\
\text { None } \\
\text { Gelatin, 1\% } \\
\text { Gelatin, 4\% } \\
\text { Albizia gum, 1\% } \\
\text { Albizia gum, 4\% }\end{array}$ & $\begin{array}{l}0.312 \\
0.318 \\
0.384 \\
0.781 \\
0.605 \\
0.988\end{array}$ \\
\hline DL & $\begin{array}{l}\text { Direct compression } \\
\text { Wet granulation }\end{array}$ & $\begin{array}{l}\text { None } \\
\text { None } \\
\text { Gelatin, 1\% } \\
\text { Gelatin, 4\% } \\
\text { Albizia gum, 1\% } \\
\text { Albizia gum, 4\% }\end{array}$ & $\begin{array}{l}0.320 \\
0.331 \\
0.392 \\
0.811 \\
0.658 \\
1.210\end{array}$ \\
\hline $\mathrm{DDCP}$ & $\begin{array}{l}\text { Direct compression } \\
\text { Wet granulation }\end{array}$ & $\begin{array}{l}\text { None } \\
\text { None } \\
\text { Gelatin, } 1 \% \\
\text { Gelatin, } 4 \% \\
\text { Albizia gum, 1\% } \\
\text { Albizia gum, 4\% }\end{array}$ & $\begin{array}{l}0.328 \\
0.375 \\
0.404 \\
0.881 \\
0.683 \\
1.410\end{array}$ \\
\hline
\end{tabular}




\section{Microbial survival during tabletting}

Table IV shows the values of log percent survival with compression pressure in diclofenac formulations. Plots of $\log \%$ survival of Bacillus subtilis spores in the tablets against compression pressure for diclofenac formulations are shown in Figure 4.

An inverse linear relationship between $\log \%$ survival and compression pressure with correlation coefficient of 0.956 to 0.996 was obtained in all the formulations with both types of binders and at all concentrations used. These correlations were significant $(\mathrm{p}<0.05)$. Such linear relationship between $\log \%$ survival of microorganisms and compression pressure has been reported for other pharmaceutical preparations in previous works (Rasenack, Muller, 2002; Roberts, Rowe, 1996; Fichtner, 2007; Bashaiwoldu et al., 2004; Ayorinde et al., 2005).

DCS, the most plastic formulation as evidenced by the lowest values of both $\mathrm{P}_{\mathrm{y}}$ and $\mathrm{P}_{\mathrm{k}}$, was found to exhibit the highest reduction in viability of the microbial contaminant. The ranking of reduction of viability among diclofenac formulations was DCS $>$ DL $>$ DDCP. At a compression pressure of $226.46 \mathrm{MN} / \mathrm{m}^{2}$, DCS had a reduction of viability of $94 \%$, DL had $90 \%$ while DDCP had $88 \%$. Plastic deformation which was the main mechanism of consolidation in DCS led to greater interparticulate contact, thereby enhancing greater mechanical disruption of the microorganisms than DL and DDCP formulations.

Significantly $(p<0.05)$ higher microbial survival was obtained in powder formulations prepared by direct compression than in granule formulations prepared using

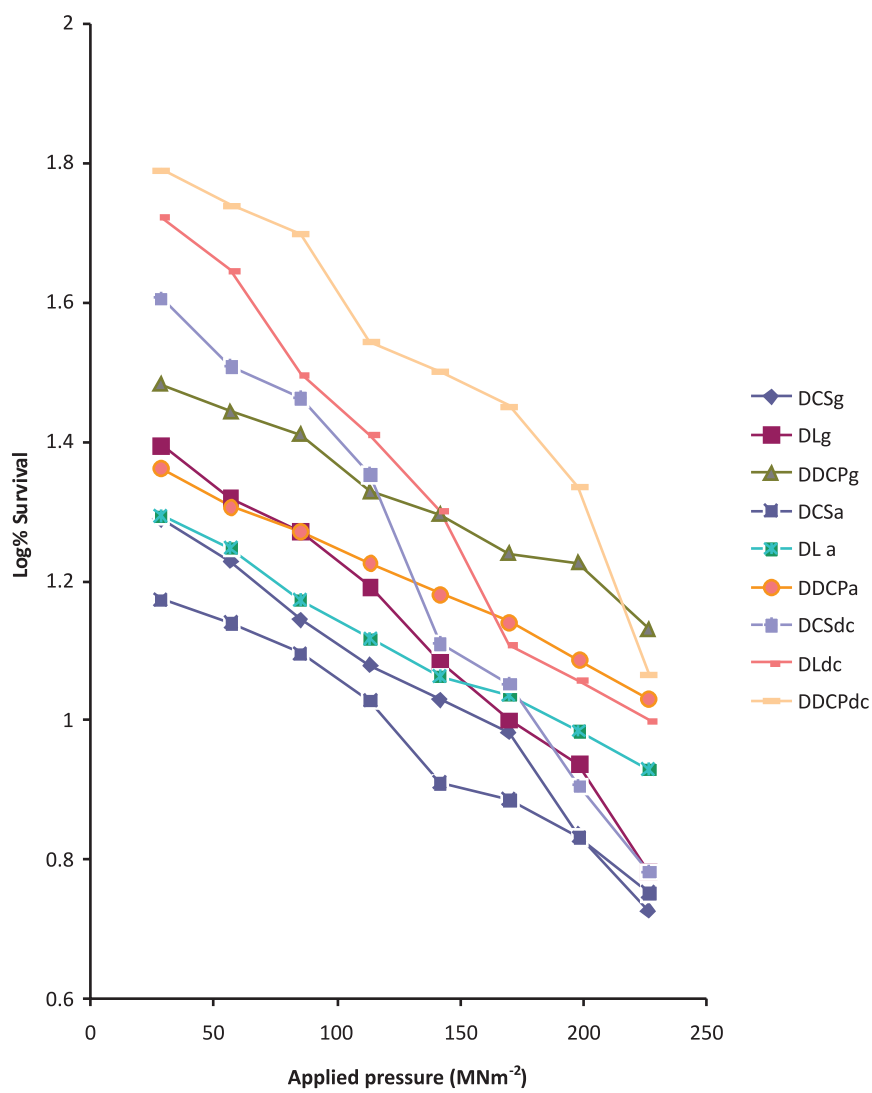

FIGURE 4 - Log\% survival versus applied pressure, (p).

TABLE IV - Values of Log\% Survival of Bacillus subtilis Spores in Diclofenac Formulations at the Compression pressure of 226.46 $\mathrm{MN} / \mathrm{m}^{2}$

\begin{tabular}{lllr}
\hline Formulation & Compression Method & Binder/Concentration & Log\% Survival \\
\hline DCS & Direct compression & None & 0.864 \\
& Wet granulation & None & 0.783 \\
& & Gelatin, 1\% & 0.727 \\
& & Gelatin, 4\% & 0.636 \\
& & Albizia gum, 1\% & 0.609 \\
\hline DL & Direct compression & Albizia gum, 4\% & 1.000 \\
& Wet granulation & None & 0.930 \\
& & None & 0.883 \\
& & Gelatin, 1\% & 0.860 \\
& & Gelatin, 4\% & 0.830 \\
DDCP & Albizia gum, 1\% & 0.809 \\
& & Albizia gum, 4\% & 1.267 \\
& Direct compression & None & 1.177 \\
& Wet granulation & None & 1.131 \\
& & Gelatin, 1\% & 1.026 \\
& & Gelatin, 4\% & Albizia gum, 1\% \\
& & Albizia gum, 4\% & 0.983 \\
\hline
\end{tabular}


the wet granulation method (with no binder). To form granules, bonds must be formed between powder particles so that they adhere, and these bonds must be sufficiently strong to prevent breakdown of the granules to powder in subsequent handling operations. These strong interparticulate bonds are capable of a lethal effect on microorganisms. It is known that granulation steps prior to compression into tablets often employ temperatures in excess of $50{ }^{\circ} \mathrm{C}$ and are therefore detrimental to microbial survival. Fry and Greaves (1995) reported that wet granulation led to a reduction in microbial contaminants.

The results further show that, in all the formulations, the percent survival of Bacillus subtilis spores decreased with increase in binder concentration and formulations containing Albizia gum exhibited a higher reduction of viability of the microbial contaminant than those containing gelatin. The difference was significant $(\mathrm{p}<0.05)$. This suggests that Albizia zygia gum is capable of reducing the survival level of microbial contaminants in the formed tablets.

\section{CONCLUSION}

The study showed that Albizia gum is capable of imparting higher plasticity and improving the softness of materials as evidenced by lower values of $\mathrm{P}_{\mathrm{y}}$ and $\mathrm{P}_{\mathrm{k}}$ in the formulations containing Albizia gum than those containing gelatin. Tablets containing Albizia gum were found to possess higher tensile strength than those containing the synthetic binder gelatin, thus suggesting that using Albizia gum as binder in tablet formulations is capable of producing tablets of satisfactory mechanical strength. Furthermore, tablets prepared with Albizia gum showed a higher reduction of viability of Bacillus subtilis spores than those with gelatin. This therefore suggests that Albizia gum has a greater lethal effect on microbial contaminants than gelatin.

\section{REFERENCES}

ADAMS M. J.; MULliER, M.A.; SEVILLE, J.P.K. Agglomerate strength measurement using a uniaxial confined compression test. Powder Technol., v.78, p.5-13, 1994.

AKANDE O. F.; FORD, J.L.; ROWE, P.H.; RUBINSTEIN, M.H. The effects of lag-time and dwell-time on the compaction properties of $1: 1$ paracetamol/microcrystalline cellulose tablets prepared by pre-compression and main compression. J. Pharm. Pharmacol., v.50, n.1, p.19-28, 2009.
ALEBIOWU, G.; ITIOLA, O.A. Effects of natural and pregelatinized sorghum, plantain and corn starch binders on the compressional characteristics of a paracetamol tablet formulation. Pharm. Technol., [Suppl. Ed:Drug Delivery] p.26-30, 2001.

AYORINDE, J.O.; ODEKU, O.A.; ITIOLA, O.A. The survival of Bacillus subtilis spores in dicalcium phosphate, lactose and corn starch, and their binary mixtures during tabletting. Pharm. Technol., v.29, n.12, p.56-64, 2005.

AYORINDE, J.O; ITIOLA, O. A. Individual and interacting effecst of formulation variables on the tensile strength and microbial survival in diclofenac tablets. Arch. Pharm. Res., v.33, n.3, p.395-403, 2010.

BASHAIWOLDU, A.B.B.; PODCZECK, F.; NEWTON, M. A study on the effect of drying techniques on the mechanical properties of pellets and compacted pellets. Eur. J. Pharm. Sci., v.21, n.2/3, p.119-129, 2004.

BLAIR, T.C.; BUCKTON, G.; BLOOMFIELD, S. Mechanism of kill of microbial contaminants during tablet compression. Int. J. Pharm., v.72, n.2, p.111-115, 1991.

CELIK, M.; DRISCOLL, C.E. An overview of the effects of some physicochemical and mechanical characteristics of particulates on the compaction and post-compaction properties of compacts. Drug Dev. Ind. Pharm., v.19, n.17/18, p.2119-2141, 1993.

CHESWORTH, K.A.C; SINCLAIR, A; STRETTON, R.J; HAYES, W.P. Effect of tablet compression on the microbial count of tablet ingredients. Microbios. Lett., v.4, p.41-45, 1977.

FASSIHI, A.R; PARKER, M.S. The effects of processing factors upon the microbial content of tablets. J. Appl. Bacteriol., v.17, p. 17. 1977.

FELL, J. T; NEWTON, J. M. Determination of tablet strength by diametral compression test. J. Pharm. Sci., v.59, n.5, p.688-691, 1970.

FICHTNER, F. Identification and variation of some functionality related characteristics of pharmaceutically relevant solid materials and their effects on product performance. Uppsala, 2007. 92 p. [Ph.D thesis. Faculty of Pharmacy, Uppsala University]. 
FRY, R.M; GREAVES, R.I.N. The survival of bacteria during and after drying. J Hyg-Cambridge, v.49, n.2/3, p.220-246, 1995.

GEORGET, D.M.R; PARKER, R; SMITH, A.C. A study of the effects of water content on the compaction behavior of breakfast cereal flakes. Powder Technol., v.81, n.2, p.189$195,1994$.

HECKEL, R.W. An analysis of powder compaction behavior. Trans. Metallurgical Society, AIME., v.221, p.1001-1007, 1961.

ITIOLA, O.A; PILPEL, N. Tabletting characteristics of metronidazole formulations. Int. J. Pharm., v.31, n.1/2, p.99-105, 1986b.

ITIOLA, O.A; PILPEL, N. Formulation effects on the mechanical properties of metronidazole tablets. J. Pharm. Pharmacol.,v.43, n.3, p.145-147, 1991.

KAWAKITA, K; HATTORI, I; KISHIGAMI, M. Characteristic constants in Kawakita's compression equations. J. Powder Bulk Solids Technol. v.1, p.3-8, 1977.

LUANGTANA-ANA, M.; FELL, J.T. Bonding mechanisms in tabletting. Int. J. Pharm., v. 60, n.3, p.197-202, 1990.

NESIC, M. Consolidation mechanism of ethyl cellulose system and iron sulphate-ethyl cellulose system. Acta Pharm. Jugosl. v.37, p.175-182, 1987.

ODEKU, O.A; ITIOLA, O.A; ODELOLA, H. A. Evaluation of destructive effects of khaya gum on bacillus subtilis spores during tabletting. Phytother. Res., v.13, n.4, p.296299, 1999.

ODENIYI, M.A; JAIYEOBA, K.T. Optimization of ascorbic acid tablet formulations containing hydrophilic polymers. Farmacia, v.57, n.2, p.157-166, 2009.

PARKER, M.S. The Preservation of oral dosage forms. Int. J. Pharm. Technol. Prod. Mfr., v.5, p.20-24, 1985.
PLUMPTON, E.J.; GILBERT, P.; FELL, J.T. Effects of spatial distribution of contaminating microorganisms within tablet formulation on subsequent inactivation through compaction. Int. J. Pharm., v.30, n.2/3, p.237-240, 1986.

RASENACK, N.; MULLER, B.W. Crystal habit and tabletting behaviour. Int. J. Pharm., v.244, n.1/2, p.45-57, 2002.

REES, J.E.; RUE, P.J. Time dependent deformation of some direct compression excipients. J. Pharm. Pharmacol., v.30, n.10, p.601-607, 1978.

ROBERTS, R.J.; ROWE, R.C. The effects of relationship between punch velocity and particle size on the compaction behavior of materials with varying deformation mechanisms. J. Pharm. Pharmacol., v.38, n.8, p.566-571, 1986.

ROBERTS, R.J; ROWE, R.C. Brittle /ductile behaviour in pharmaceutical materials used in tabletting. Int. J. Pharm., v.36, n.2/3, p.205-209, 1996.

SUJJA-AREEVATH, J; MUNDAY, D.L; COX, P.J; KHAN, K.A. Release characteristics of diclofenac sodium from encapsulated natural gum mini-matrix formulations. Int. J. Pharm, v.139, n.1/2, p.53-62, 1996.

TYLER, V.E.; BRADY, L.R.; ROBERTS, J.E. (Eds.). Pharmacognosy. 12.ed. Philadelphia: Lea and Febiger, 1983. p.338-367.

WALLHAUSER, K.H. Microbiological aspects on the subject of oral dosage forms. Pharm. Ind. v.39, p.491-497, 1977.

WORLD AGROFORESTRY. Albizia zygia. <www. worldagroforestry.org/treedb2/speciesprofile. php?Spid=1749>. Accessed on: 28 aug. 2011.

Received for publication on $16^{\text {th }}$ June 2011 Accepted for publication on $19^{\text {th }}$ September 2011 